\title{
Hubungan Kekerapan Pemberian Kolostrum dan Cara Lahir dengan Jumlah Koloni Bakteri Asam Laktat di Saluran Cerna Neonatus
}

\author{
Suci Rahmani Nurita ${ }^{1}$, Mayetti ${ }^{2}$, Masru| ${ }^{3}$ \\ ${ }^{1}$ Pascasarjana IImu Kebidanan Fakultas Kedokteran Universitas Andalas, Padang \\ ${ }^{2}$ Pediatri, Fakultas Kedokteran Universitas Andalas, Padang \\ ${ }^{3}$ IImu Gizi, Fakultas Kedokteran Universitas Andalas, Padang \\ e-mail: sucirahmani85@gmail.com
}

\begin{abstract}
One of the biggest causes of infant mortality is an infectious diseases. Infectious diseases can be prevented through breastfeeding especially colostrum which is rich in nutrients, bioactive components, immunomodulatory factors and microbiota which play a role in the formation and development of the baby's immune system. Lactic Acid Bacteria $(L A B)$ is one of the microbiota that plays an important role. This study aims to determine the relationship between frequency of colostrum and birth mode with the number of $L A B$ colonies in the neonatal gastrointestinal tract. This study was observational with a cross sectional approach on 61 postpartum mothers and newborns at 2 hospitals (Reksodiwiryo Hospital and DR. Rasyidin Hospital) and 4 Independent Midwives Practice (BPM) in the Andalas, Ambacang and Belimbing Community Health Centre. Samples were obtained by consecutive sampling. The sample examination were done in the Microbiology Laboratory of Animal Product Technology, Faculty of Animal Science, Andalas University, Padang. Data analysis using T-Independent test and Pearson correlation test. The statistical test results showed no significant differences in the number of $L A B$ colonies in the first 24 hours of birth in the neonatal gastrointestinal tract between those who were vaginally and $C$-section born $(p=0.911)$ and there was a significant relationship between the frequency of colostrum and the number of $L A B$ colonies in the neonatal gastrointestinal tract on the 4th day births with a very strong correlation and a positive direction $(p=0,000 ; r=(+)$ 0.91). In this study it can be concluded that the number of $L A B$ colonies in neonates born of vaginal and $C$-section not much different, this is due to colonization of $L A B$ in the neonatal gastrointestinal tract can occur before birth. The more often colostrum is given, the more number of $L A B$ colonies in the neonatal gastrointestinal tract.
\end{abstract}

Keywords:

Lactic Acid Bacteria, Frequency of Colostrum, Birth Mode

\section{PENDAHULUAN}

Angka Kematian Bayi merupakan salah satu indikator yang menentukan derajat kesehatan. Setiap tahun terjadi 3 juta kematian bayi pada periode neonatal awal di dunia. Sembilan puluh delapan persen kematian terjadi di negara berkembang (World Health Organization, 2006). Menurut Survey Demografi dan Kesehatan Indonesia (SDKI) tahun 2012, $60 \%$ kematian bayi terjadi pada masa neonatus (Badan Pusat Statistik, 2013). Tahun 2014, estimasi Angka Kematian Bayi (AKB) di Indonesia mencapai 23 kematian per 1.000 kelahiran hidup (Kementerian Kesehatan, 2016). Sebanyak $40 \%$ kematian bayi disebabkan oleh penyakit infeksi seperti diare dan Infeksi Saluran Pernapasan Akut (ISPA) (Aldy et al. 2009).

Tahun 2012, Dinas Kesehatan Provinsi Sumatera Barat melaporkan estimasi AKB di Sumatera Barat mencapai 27 per 1000 kelahiran hidup (Dinas Kesehatan Provinsi Sumatera Barat, 2015). Bayi yang berusia kurang dari 1 bulan merupakan golongan umur yang paling rentan terhadap resiko gangguan kesehatan. Pada tahun 2014, terdapat jumlah kematian neonatal di Provinsi Sumatera Barat sebanyak 689 orang dengan kematian neonatal tertinggi di Kota Padang sebesar 11,03\%, Kecamatan Kuranji memiliki proporsi tertinggi yaitu 19,73\% (Dinas Kesehatan Kota Padang, 2015).
Menurut Mosley dan Chen, kematian bayi yang masih tinggi di negara berkembang disebabkan oleh beberapa faktor, diantaranya karakteristik ibu (umur, paritas dan jarak kelahiran), kontaminasi lingkungan, gizi, kecelakaan dan penyakit. Sehubungan dengan hal itu, pada awal kehidupannya bayi memerlukan pemenuhan gizi melalui Air Susu Ibu (ASI).

Sebanyak 5.929 bayi berumur 0-6 bulan yang tercatat di Kota Padang tahun 2014, hanya $55,6 \%$ dari 873 bayi yang berada di wilayah kerja Puskesmas Lubuk Buaya mendapat ASI eksklusif. Sebesar $80,7 \%$ dari 564 bayi yang berada di wilayah kerja Puskesmas Andalas mendapat ASI eksklusif diikuti wilayah kerja Puskesmas Belimbing, 85,6\% dari 672 bayi mendapat ASI eksklusif (Dinkes Kota Padang, 2015).

United Nation Children's Fund (UNICEF) menyatakan sebanyak 30.000 kematian bayi di Indonesia dapat dicegah melalui pemberian ASI. Air Susu Ibu merupakan makanan bayi berstandar emas yang pemberiannya dimulai dengan Inisiasi Menyusui Dini (IMD), pemberian kolostrum, ASI eksklusif hingga 6 bulan, MP-ASI setelah bayi 6 bulan dan tetap memberikan ASI sampai bayi berusia 2 tahun (Maryunani, 2012; BPS, 2013). 
Hasil penelitian terhadap 11.000 bayi baru lahir (usia < 28 hari) di Inggris, 22\% bayi dapat terselamatkan jika mendapat kolostrum secara maksimal. Hajeebhoy et al. juga menemukan bayi yang mendapatkan kolostrum mendapat protektif lebih besar dari ancaman infeksi diare dan ISPA daripada bayi yang tidak mendapat kolostrum (Pollard, 2015; Djaiman \& Sihadi, 2015; Edmond et al. 2006).

Saluran cerna merupakan organ terpenting yang berperan dalam pertumbuhan, perkembangan dan kesehatan anak. Proses maturasi saluran cerna distimulasi oleh ASI yang difasilitasi oleh kolostrum. Kolostrum yang disekresi oleh kelenjar payudara pada hari ke-1 hingga hari ke-4 setelah kelahiran mengandung komponen bioaktif dan mikrobiota menguntungkan dimana berperan dalam menciptakan keseimbangan mikrobiota saluran cerna neonatus yang berpengaruh terhadap maturasi dan perkembangan sistem imun saluran cerna bayi baru lahir (Ikatan Dokter Anak Indonesia, 2008).

Mikrobiota saluran cerna berperan penting terhadap kesehatan host yang ditempatinya meliputi fungsi fisiologis, struktural dan metabolisme. Salah satu mikrobiota saluran cerna yang berperan penting terhadap kesehatan manusia adalah Bakteri Asam Laktat (BAL). Bakteri asam laktat merupakan kelompok bakteri yang mampu mengubah karbohidrat (glukosa) menjadi asam laktat. Untuk mengetahui mikrobiota di saluran cerna biasanya digunakan feses yang ditanam pada berbagai media dan berbagai metode kultur untuk menentukan mikrobiota tersebut (Rahmagiarti et al. 2013; Syukur \& Purwati, 2013).

Manfaat BAL sudah banyak diteliti diantaranya merangsang daya tahan tubuh baik seluler maupun humoral, meningkatkan kemampuan penyerapan beberapa nutrisi, menjaga $\mathrm{PH}$ usus sehingga dapat melindungi dari mikroorganisme patogen, menjaga gangguan dalam penyerapan air, melancarkan pencernaan dengan memproduksi beberapa enzim pencernaan dan vitamin, meningkatkan pergerakan usus sehingga membebaskan konstipasi dan menghasilkan subtansi antibakteri yang mampu membunuh mikroorganisme patogen penyebab penyakit infeksi (Syukur \& Purwati, 2013).

Beberapa penelitian menunjukkan bahwa ASI terutama kolostrum merupakan sumber BAL terbesar bagi bayi. Beberapa genus bakteri yang termasuk dalam kelompok BAL diantaranya Lactobacillus, Streptococcus dan Bifidobacteria yang dominan terdapat pada feses bayi yang mendapat ASI (Mcguire \& Mcguire, 2015; Lee et al. 2015).
Semakin sering bayi menyusui maka semakin banyak komponen bioaktif dan mikrobiota ASI yang ditransfer dari ibu ke bayi. Kent et al. (2005) menemukan rerata kekerapan atau frekuensi bayi menyusu pada ibunya dalam 24 jam adalah sebanyak 11 kali penyusuan dengan rentang 6-18 kali penyusuan. Yoshioka et al. dalam Rahmagiarti et al. (2013) melaporkan pada saluran cerna bayi yang mendapat ASI ketika berusia 4 hari, menunjukkan adanya strain bifidobacterium dan akan meningkat pada usia 7 hari. Bifidobacterium akan lebih stabil mendominasi lingkungan usus bayi saat berusia 1 bulan.

Faktor-faktor yang mempengaruhi kolonisasi mikrobiota di saluran cerna neonatus pada bayi baru lahir adalah cara kelahiran bayi, jenis asupan nutrisi bayi (ASI atau susu formula), usia kehamilan, diet ibu, rawat inap bayi (lingkungan) dan penggunaan antibiotik (Penders et al. 2005). Bayi lahir melalui 2 cara yakni lahir pervaginam dan lahir secara operasi sesar yaitu melalui insisi pada dinding abdomen (perabdominal) dan dinding uterus (Cunningham et al. 2012). Terdapat perbedaan komposisi mikrobiota saluran cerna pada bayi baru lahir antara bayi yang lahir dengan operasi caesar dengan bayi yang lahir secara pervaginam (Biasucci et al. 2008). Bayi yang lahir pervaginam akan terkolonisasi sejak awal oleh mikrobiota yang berasal dari vagina ibu (Kusumo, 2012).

Jimenez et al. (2008) melaporkan dalam mekonium (2 jam setelah kelahiran dan sebelum bayi disusui), sebagian sampel didominasi oleh bakteri asam laktat dari strain Lactobacillus sedangkan sebagian lain didominasi oleh bakteri enterik sejenis E.Coli. Spesies mikrobiota yang ditemukan pada bayi yang lahir pervaginam ialah Lactobacillus $s p$. dan Prevotella $s p$. Sedangkan mikrobiota yang lahir secara sesar adalah Clostridium sp., Staphylococcus sp., dan Propionobacterium sp. (Collado et al. 2012). Penelitian Hansen et al. (2015) pada feses 24 jam pertama setelah lahir, menemukan adanya jumlah bakteri yang rendah pada mekonium pertama. Satu bayi didominasi oleh Enterobacteriaceae, sementara sampel lain didominasi 2-5 genus bakteri seperti Bifidobacterium, Enterobacteriaceae, Enterococcaceae dan Bacteroides Prevotella.

Berdasarkan uraian diatas menjadi dasar peneliti untuk meneliti hubungan kekerapan pemberian kolostrum dan cara lahir dengan jumlah koloni bakteri asam laktat di saluran cerna neonatus.

Tujuan penelitian ini adalah untuk mengetahui hubungan kekerapan pemberian kolostrum dan cara lahir dengan jumlah koloni bakteri asam laktat di saluran cerna neonatus. 


\section{METODE PENELITIAN}

Penelitian ini merupakan penelitian observasional dengan rancangan cross sectional. Populasi penelitian adalah semua ibu postpartum dari kehamilan aterm yang memiliki dan menyusui bayinya berusia $\leq 4$ hari dengan berat badan lahir normal di BPM atau RB Wilayah Kerja Puskesmas Andalas, Belimbing dan Ambacang serta Instalasi Rawat Inap Kebidanan di RS TK III DR. Reksodiwiryo dan RSUD DR. Rasyidin. Sampel pada penelitian ini berjumlah 61 ibu postpartum dan bayi baru lahir yang memenuhi kriteria inklusi dan ekslusi.

\section{HASIL DAN PEMBAHASAN}

Pengumpulan data dan sampel telah dilaksanakan mulai tanggal 22 Oktober sampai dengan 22 Desember 2017 di RS Tingkat III DR. Reksodiwiryo Padang, RSUD Dr Rasidin Padang, Wilayah Kerja Puskesmas Ambacang, Wilayah Kerja Puskesmas Belimbing, dan Wilayah Kerja Puskesmas Andalas. Semua sampel yang terkumpul dibawa ke Laboratorium Mikrobiologi Teknologi Hasil Ternak (THT) Fakultas Peternakan Universitas Andalas Padang untuk dilakukan pemeriksaan jumlah koloni Bakteri Asam Laktat (BAL) dimana hasil pemeriksaan laboratorium selesai dilakukan pada bulan Februari 2018.

Jumlah koloni bakteri asam laktat 24 jam pertama kelahiran diperiksa melalui mekonium bayi yang pertama keluar dalam 24 jam pertama kelahiran. Sampel mekonium diambil sebanyak 2 gram dan sampel yang terkumpul segera dibawa ke Laboratorium Mikrobiologi THT Fakultas Peternakan Universitas Andalas untuk dilakukan pemeriksaan.

Rerata jumlah koloni bakteri asam laktat 24 jam pertama kelahiran dapat dilihat pada tabel 1.

Tabel 1 Rerata Jumlah Koloni BAL 24 Jam Pertama Kelahiran di Saluran Cerna Neonatus

\begin{tabular}{lcc}
\hline & $\mathrm{n}$ & $\begin{array}{l}\text { Mean } \pm S D \\
\left(\log _{10}\right)\end{array}$ \\
\hline $\begin{array}{l}\text { Jumlah BAL Mekonium I } \\
\text { Kelompok Pervaginam } \\
\text { (CFU/gram) }\end{array}$ & 35 & $8,286 \pm 0,187$ \\
\hline $\begin{array}{l}\text { Jumlah BAL Mekonium I } \\
\text { Kelompok Perabdominal } \\
\text { (CFU/gram) }\end{array}$ & 26 & $8,291 \pm 0,127$ \\
\hline $\begin{array}{l}\text { Jumlah BAL Mekonium I } \\
\text { Seluruh Responden } \\
\text { (CFU/gram) }\end{array}$ & 61 & $8,289 \pm 0,163$ \\
\hline
\end{tabular}

Berdasarkan tabel 1 dapat dilihat masingmasing rerata jumlah koloni BAL 24 jam pertama kelahiran pada seluruh responden, kelompok pervaginam dan kelompok perabdominal masing-masing adalah $8,289 \pm 0,163 \quad \log _{10}$ CFU/gram, 8,286 $\pm 0,187 \quad \log _{10} \mathrm{CFU} / \mathrm{gram}$ dan $8,291 \pm 0,127 \log _{10}$ CFU/gram.
Tabel 2 Rerata Kekerapan Pemberian Kolostrum dalam 4 Hari Pertama Kelahiran antara Kelompok Pervaginam dan Perabdominal

\begin{tabular}{|c|c|c|c|}
\hline & \multicolumn{2}{|c|}{ Kelompok Responden } & $p$ \\
\hline & Pervaginam & Perabdominal & \\
\hline $\begin{array}{c}\text { Kekerapan } \\
\text { Pemberian } \\
\text { Kolostrum } \\
\text { (kali penyusuan) }\end{array}$ & $19,80 \pm 4,086$ & $17,35 \pm 3,452$ & $0,016^{*}$ \\
\hline
\end{tabular}

Berdasarkan tabel 2 dapat dilihat bahwa kelompok pervaginam (normal) memiliki rerata kekerapan pemberian kolostrum lebih banyak daripada kelompok perabdominal. Hasil uji statistik menunjukkan bahwa nilai $p<0,05$ yang berarti lebih sering dan berbeda bermakna kekerapan pemberian kolostrum pada kelompok pervaginam dibandingkan dengan kelompok perabdominal.

Jumlah koloni bakteri asam laktat pada hari ke-4 kelahiran diperiksa melalui feses bayi yang diambil pada hari ke-4 kelahiran sebanyak 2 gram. Sampel feses yang terkumpul segera dibawa ke Laboratorium Mikrobiologi THT Fakultas Peternakan Universitas Andalas untuk dilakukan pemeriksaan jumlah koloni BAL yang ada.

\begin{tabular}{ccc}
$\begin{array}{c}\text { Tabel } 3 \text { Rerata Jumlah Koloni BAL Pada Hari Ke-4 } \\
\text { Kelahiran di Saluran Cerna Neonatus }\end{array}$ \\
\hline & $\mathrm{n}$ & $\begin{array}{c}\text { Mean } \pm \text { SD } \\
\left(\log _{10}\right)\end{array}$ \\
\hline $\begin{array}{c}\text { Jumlah BAL Feses II } \\
\text { Kelompok Pervaginam } \\
\text { (CFU/gram) }\end{array}$ & 35 & $7,647 \pm 0,302$ \\
\hline $\begin{array}{c}\text { Jumlah BAL Feses II } \\
\text { Kelompok Perabdominal } \\
\text { (CFU/gram) }\end{array}$ & 26 & $7,554 \pm 0,259$ \\
\hline $\begin{array}{c}\text { Jumlah BAL Feses II } \\
\text { Seluruh Responden } \\
\text { (CFU/gram) }\end{array}$ & 61 & $7,608 \pm 0,286$ \\
\hline
\end{tabular}

Berdasarkan tabel 3 dapat dilihat masingmasing rerata jumlah koloni BAL pada hari ke-4 kelahiran pada seluruh responden, kelompok pervaginam dan kelompok perabdominal maasing-masing adalah 7,608 $\pm 0,286 \quad \log _{10}$ CFU/gram, 7,647 $\pm 0,302$ log 10 CFU/gram dan $7,554 \pm 0,259 \log _{10} \mathrm{CFU} / \mathrm{gram}$

Hubungan cara lahir dengan jumlah koloni bakteri asam laktat di saluran cerna neonatus dalam 24 jam pertama kelahiran dianalisis dengan menggunakan uji komparatif yakni uji $T$ Independent. Hasil uji statistik tersebut dapat dilihat pada tabel 4: 
Tabel 4 Perbedaan Jumlah Koloni Bakteri Asam Laktat di Saluran Cerna Neonatus Dalam 24 Jam Pertama Kelahiran Berdasarkan Cara Lahir

\begin{tabular}{lccc} 
Cara Lahir & \multicolumn{2}{l}{$\begin{array}{l}\text { Jumlah BAL dalam } 24 \text { jam pertama } \\
\text { kelahiran (CFU/gram) }\end{array}$} \\
\cline { 2 - 4 } & $\mathrm{n}$ & $\begin{array}{c}\text { Mean } \pm \text { SD } \\
\left(\log _{10}\right)\end{array}$ & $p$ \\
\hline Pervaginam & 35 & $8,286 \pm 0,187$ & 0,911 \\
Perabdominal & 26 & $8,291 \pm 0,127$ & \\
\hline
\end{tabular}

Pada Tabel 4 dari hasil uji statistik diperoleh nilai $p=0,911$, karena nilai $p>0,05$ dapat disimpulkan tidak terdapat perbedaan bermakna jumlah koloni bakteri asam laktat di saluran cerna neonatus dalam 24 jam pertama kelahiran antara kelompok pervaginam dan kelompok perabdominal yang berarti tidak ada hubungan antara cara lahir dengan jumlah koloni bakteri asam laktat di saluran cerna neonatus.

$$
\text { Hubungan kekerapan pemberian }
$$

kolostrum dengan jumlah koloni bakteri asam laktat pada hari ke-4 kelahiran dilakukan dengan uji korelasi Pearson. Hasil uji tersebut dapat dilihat pada gambar 1:

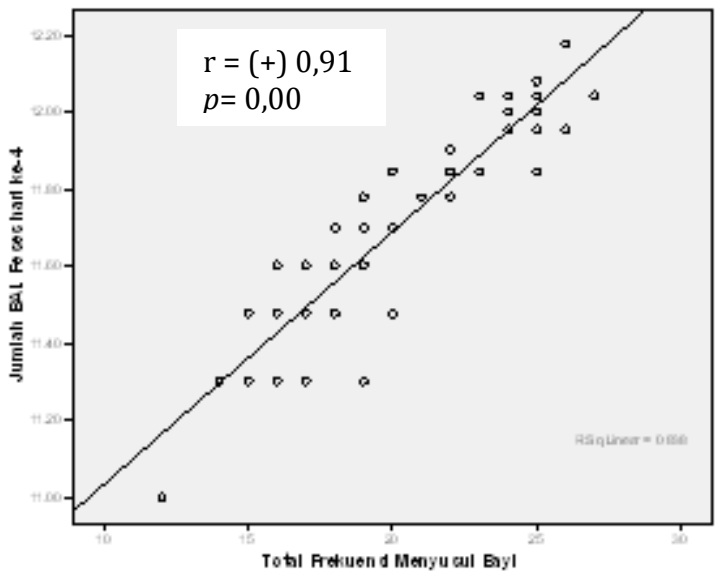

Gambar 1 Scatter Plot Hubungan Kekerapan Pemberian Kolostrum dengan Jumlah Koloni Bakteri Asam Laktat di Saluran Cerna Neonatus Pada Hari Ke-4 Kelahiran.

Pada Gambar 1 dapat diketahui bahwa terdapat hubungan yang bermakna antara kekerapan pemberian kolostrum dan jumlah koloni bakteri asam laktat pada hari ke-4 kelahiran dengan kekuatan hubungan sangat kuat dan arah korelasi positif $(p=0,00 ; r=(+) 0,91)$ yang berarti semakin kerap kolostrum diberikan semakin banyak jumlah koloni bakteri asam laktat pada hari ke-4 kelahiran.

\section{Pembahasan}

Pada penelitian ini didapatkan rerata kekerapan pemberian kolostrum dalam 4 hari pertama kelahiran bayi pada kelompok pervaginam lebih tinggi daripada kelompok perabdominal. Metode persalinan mempunyai hubungan yang signifikan dengan pemberian ASI awal (kolostrum) dimana pemberian ASI awal pada wanita yang melahirkan pervaginam 4,9 kali lebih besar dibandingkan wanita yang melahirkan perabdominal (Virarisca et al. 2010).

Menurut hasil studi Astuti (2015), praktik pemberian kolostrum pada bayi baru lahir berhubungan dengan faktor pengetahuan ibu, dukungan tenaga kesehatan (bidan) dan paparan promosi ASI awal (kolostrum). Astuti (2015) menemukan pada 100 ibu postpartum hari keempat hingga ketujuh di sebuah rumah bersalin, $73 \%$ ibu postpartum memberikan kolostrum secara sempurna. Faktor yang paling berpengaruh adalah paparan promosi ASI (kolostrum) dimana responden yang mendapat paparan promosi memiliki peluang 13 kali lebih tinggi daripada yang tidak mendapat paparan promosi untuk memberikan kolostrum pada bayinya.

Jumlah koloni BAL 24 jam pertama kelahiran antara kelompok pervaginam dan perabdominal tidak jauh berbeda. Pada penelitian ini didapatkan mekonium bayi baru lahir baik dari kelahiran pervaginam maupun kelahiran perabdominal mengandung bakteri khususnya jenis bakteri asam laktat. Hal ini memunculkan dugaan bahwa kolonisasi bakteri dapat terjadi sebelum kelahiran.

Diperkuat dari hasil studi yang menemukan adanya mikrobiota dalam plasenta, darah tali pusat, cairan amnion serta mekonium janin yang menunjukkan bahwa proses kolonisasi dimulai dengan baik sebelum kelahiran bayi. Aagaard et al. (2014) berhasil mengkarakterisasi profil mikrobiota plasenta yang terdiri dari mikrobiota komensal seperti Firmicutes, Tenericutes, Proteobacteria, Bacteroidetes, dan Fusobacteria filum dimana memiliki beberapa kesamaan dengan mikrobiota pada mulut manusia. Jimenez et al. (2005) juga menemukan spesies bakteri yang diisolasi dari darah tali pusat (Enterococcus faecium, Propionibacterium acnes, Staphylococcus epidermidis, dan Streptococcus sanguinis) dimana bakteri ini merupakan mikrobiota mulut dan usus ibu. Hasil temuan Ardissone et al. (2014) juga memperkuat bahwa mikrobiota pada mekonium didapat neonatus selama dalam kandungan dimana mikrobiota yang terdapat pada mekonium sama dengan mikrobiota yang terdapat pada cairan amnion karena ketika sistem saraf janin mulai berkembang, janin dapat menelan cairan amnion.

Jumlah koloni BAL pada hari ke-4 kelahiran pada kelompok pervaginam lebih banyak dari kelompok perabdominal dikarenakan kelompok pervaginam melakukan pemberian kolostrum lebih awal dan memiliki kekerapan pemberian kolostrum lebih banyak dibandingkan kelompok perabdominal. Beberapa hasil studi menjelaskan bakteri asam laktat didapat dari kolostrum (Murphy et al. 
2017). Bakteri yang terdapat pada kolostrum dominan berasal dari kulit payudara dan pencernaan ibu (Latuga et al. 2014). Hasil sebuah studi yang melakukan isolasi bakteri pada 19 sampel ASI ibu dan 19 sampel feses bayi menyimpulkan terdapat strain bakteri yang sama (Lactobacillus, Bifidobacterium, dan Staphylococcus) antara ASI dan feses bayi (Martin et al. 2012).

\section{SIMPULAN}

Tidak ada hubungan yang bermakna antara cara lahir dengan jumlah koloni BAL di saluran cerna neonatus. Terdapat hubungan yang bermakna antara kekerapan pemberian kolostrum dan jumlah koloni BAL pada hari ke-4 kelahiran dengan kekuatan hubungan sangat kuat dan arah korelasi hubungan positif.

\section{DAFTAR PUSTAKA}

Aagaard, K., Ma, J., Antony, KM., Ganu, R., Petrosino, J., Versalovic, J. et al. (2014). The Placenta Harbors a Unique Microbiome. Sci Transl Med. Vol. 6. pp. 237-259

Aldy, O.S., Lubis, B.M., Azlin, E., \& Tjipta, G.D. (2009). Dampak Proteksi Air Susu lbu Terhadap Infeksi. Sari Pediatri. Vol. 11(3). pp.167-173.

Ardissone, AN., de la cruz, DM., DavisRichardson, AG., Rechcigl, KT., Li, N., Drew, JC., et al. (2014). Meconium Microbiome Analysis Identifies Bacteria Correlated With Premature Birth. Plos One. Vol. 9(3). pp.1-8

Astuti, D. (2015). Praktik Pemberian Kolostrum Pada Bayi Baru Lahir di Kabupaten Kudus. Maternal. Vol. 12(1). pp.13-24

Badan Pusat Statistik, Badan Kependudukan dan Keluarga Berencana Nasional dan Kementerian Kesehatan. (2013). Survei Demografi dan Kesehatan Indonesia Tahun 2012. Jakarta: Badan Pusat Statistik.

Biasucci, G., Benenati, B., Morelli, L., Bessi, E., Bochm, G. (2008). Cesarean Delivery May Affect The Early Biodiversity of Intestinal Bacteria. The Journal of Nutrition. Vol. 138. pp. 1796-1800.

Collado, M. C., Cernada, M., Bauerl, C., Vento, M., Martinez, G. P. (2012). Microbial Ecology and Host-Microbiota Interactions During Early Life Stages. Gut Microbes. Vol. 3(4). pp. 352-365.

Cunningham, F. G., Leveno, K. J., Bloom, S. L., Hauth, J. C., Rouse, D. J., Spong, C. Y. (2012). Obstetri Williams (Edisi 23 Vol 1). Jakarta: EGC.

Dinas Kesehatan Kota Padang. (2015). Profil Kesehatan Kota Padang Tahun 2014. Padang: Dinas Kesehatan Kota Padang.
Dinas Kesehatan Provinsi Sumatera Barat (2015). Profil Kesehatan Sumatera Barat Tahun 2014. Padang: Dinas Kesehatan Provinsi Sumatera Barat.

Djaiman, Sri P.H. \& Sihadi. (2015). Probabilitas Waktu Seorang Ibu Menyusui Pertama Kali Bayinya dan Faktor yang Mempengaruhi. Buletin Penelitian Kesehatan. Vol. 43(4). pp. 239-246.

Edmond, K.M., Zandoch, C., Quigley, M.A., Amenga-Etego, S., Owusu-Agyei, S., \& Kirkwood, B.R. (2006). Delayed Breastfeeding Initiation Increases Risk of Neonatal Mortality. Pediatrics Official Journal of the American Academy of Pediatrics. Vol.117(3). pp.380-386.

Hansen, R., Scott, K. P., Khan, S., Martin, J. C. Berry, S. H. Stevenson, M., et al. (2015). First-Pass Meconium Samples From Healthy Term Vaginally-Delivered Neonates: An Analysis of The Microbiota. PLOS ONE. Vol.10(7).pp 1-10. Doi: 10.1371/journal.pone.0133320.

Ikatan Dokter Anak Indonesia. (2008). Bedah ASI. Jakarta: Balai Penerbit FK UI.

Jimenez, E., Fernandez, L., Maria, LM., Martin, R., Odriozola, J. M., Carmen NuenoPalop., et al. (2005). Isolation of Comensal Bacteria From Umbilical Cord Blood of Healthy Neonates Born by Cesarean Section. Current Microbiology. Vol. 51. pp. 270-274.

Jimenez, E., Marin, M. L., Martin, R., Odriozola, J. M., Olivares, M., Xaus, J., et al. (2008). Is Meconium From Healthy Newborns Actually Sterile?. Research in Microbiology. Vol. 159. pp. 187-193.

Kementerian Kesehatan Republik Indonesia. (2016). Profil Kesehatan Indonesia Tahun 2015. Jakarta: Kementerian Kesehatan Republik Indonesia.

Kent, J. C., Mitoulas, L. R., Cregan, M. D., Ramsay, D. T., Doherty, D. A., Hartman, P. E. (2005). Volume and Frequency of Breastfeeding and Fat Content of Breast Milk Throughtout The Day. American Academy of Pediatrics. Vol. 117(3). pp. e387-e395.

Kusumo, P. D. (2012). Kolonisasi Mikrobiota Normal dan Pengaruhnya Pada Perkembangan Sistem Imunitas Neonatal. Jurnal Kedokteran FKUK. Vol. 29(320). pp. 55-63.

Latuga, MS., Stuebe, A., \& Seed, PC. (2014). A Review of the Source and Function of Microbiota in Breast Milk. Semin Reprod Med. Vol. 32. pp. 68-73

Lee SA, Lim JY, Kim BS, Cho SJ, Kim NY, Kim OB et al. (2015). Comparison of the Gut Microbiota Profile in Breast-fed and Formula-fed Korean Infants Using 
Pyrosequencing. Nutrition Research and Practice. pp. 242-248.

Martin, V., Barragan, AM. Moles, L., Banos, MR., del Campo, R., Fernandes, L., et al (2012). Sharing of Bacterial Strains Between Breast Milk and Infant Feces. Journal of Human Lactation. Vol. 28(1), pp. 36-44

Maryunani, A. (2012). Inisiasi Menyusu Dini, ASI Eksklusif dan Manajemen Laktasi. Jakarta: Trans Info Media.

Mcguire, M. K., \& Mcguire, M. A.. (2015). Human Milk : Mother Nature's Prototypical. American Society for Nutrition. Vol.6. pp.112-113.

Murphy, K., Curley, D., Callaghan, T. F. O., O'Shea, C. A., Dempsey, E. M., et al. (2017). The Composition Of Human Milk and Infant Faecal Microbiota Over The First Three Months Of Life: a Pilot Study. Scientific Reports. Vol 7. pp e40597 (1-10)

Penders, J., Thijs, C., Vink, C., Stelma, F.F., Snijders, B., Kummeling, I., et al. (2005). Factors Influencing the Composition of the Intestinal Microbiota in Early Infancy. American Academy of Pediatrics. Vol 118(2). pp. 511-521.

Pollard, Maria. (2015). ASI Asuhan Berbasis Bukti. Editor MSB. Hutagalung dan EA. Mardella. Jakarta: EGC

Rahmagiarti, C., Prayitno, L., Oswari, H., \& Abinawanto. (2013). Perkembangan Kolonisasi Bifidobacterium Pada Usus Bayi. FMIPA UI. pp. 1-6

Syukur, S \& Purwati, E. (2013). Bioteknologi Probiotik Untuk Kesehatan Masyarakat. Yogyakarta: CV. Andi Offset.

Virarisca, S., Dasuki, D., Sofoewan, S. (2010). Metode Persalinan dan Hubungannya dengan Inisiasi Menyusu Dini di RSUP Dr. Sardjito Yogyakarta. Jurnal Gizi Klinik Indonesia. Vol. 7(2). pp. 92-98.

World Health Organization. (2006). Neonatal and Perinatal Mortality. Switzerland : WHO Press. 